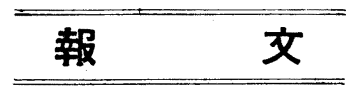

(浪速大学工学部応用化学科 *) (昭和 29 年 3 月 29 日受理)

弗化物添加クローム鍍金夜中の弗素の定量

東 野 利昌・武者宗一郎

\title{
Determination of Fluorine in the Chrome-Plating Baths \\ Containing Fluorides
}

Toshrmasa Higashino and Sórchiro Musha

(Engineering College, Naniwa University)

In the case of chrome-plating, the addition of small amounts of the various kinds of fluorides to the baths recently prevails in order to obtain the higher quality of the plate and to improve its procedure. But it has yet been difficult to control the contents of the fluorine owing to the lack of an adequate method for determining it. In the present work this method was investigated and the satisfactory results were obtained with the sample solutions containing from 0.2 to $5 \mathrm{mg}$ of fluorine per liter. The analytical procedure is as follows : $5 \mathrm{ml}$ of the solution, which is obtained by diluting the original sample solution by 75 times, is taken and the chromium is reduced to chromic by heating with the addition of $2 \mathrm{ml}$ of ethanol and $3 \mathrm{ml}$ of $N$-hydrochloric acid. Excess amounts of the chromic ion is exchanged by means of Daiya Ion $K$. The exchanged solution is added with sodium hydroxide to the faint red color of phenolphthalein and then added with $5 \mathrm{ml}$ of alum solution ( $40 \gamma$ of aluminium), $8 \mathrm{ml}$ of $N$-hydrochloric acid, $5 \mathrm{ml}$ of $3 \mathrm{~N}$ ammonium acetate, $5 \mathrm{ml}$ of $0.1 \%$ solution of aluminon and $0.5 \mathrm{ml}$ of $6 \mathrm{~N}$ ammonium carbonate. The total volume of the solution is brought up to $100 \mathrm{ml}(\mathrm{pH}=$ 4.6) and is allowed to stand in the thermostat $\left(31^{\circ} \mathrm{C}\right)$ for 45 minutes to develop the color. The amounts of fluorine are determnied by the electrophotometric method, using the calibration curve. The analytical error is $2 \%$ and the time required is 75 minutes. Silicic acid and oxalic acid interferes.

(Received March 29, 1954).

\section{緒言}

近時クローム鐇金の品質改善と鍍金操作の改良を目的 として鍍金液中に各種の弗化物の少量 $\left(\mathrm{CrO}_{3} 250 \mathrm{~g}: \mathrm{HF} 4 \mathrm{~g} / l\right.$, $\mathrm{CrO}_{3} 250 \mathrm{~g}: \mathrm{H}_{2} \mathrm{SO}_{4}(100 \%) 1.5 \mathrm{~g}: \mathrm{HF} 1 \mathrm{~g} / l$, この外 $\mathrm{HF}$ の代りに $\mathrm{H}_{2} \mathrm{SiF}_{6}, \mathrm{NH}_{4} \mathrm{~F}$ 等を $\mathrm{F}^{-}$として $0.15 \mathrm{~mol}$ 程度加えられている) を添加せられることがある゙1。 こ の添加される少量の弗素化合物は揮発性, 腐蝕性著しく 常に其の含星を制御せねばならないのに拘らず，従来適 当な定量法か見当らなかった．著者等はこの点研究を進 めイオン交換法とアルミニウムーアルミノン法2 (以下 $\mathrm{Al}-\mathrm{Al}$ 法と略称す）とによる弗素定量法を応用検討した. 先つ共存する過大量の $\mathrm{CrO}_{3}$ は $\mathrm{HCl}$ 酸性-エタノールで 還元後 $\mathrm{R}-\mathrm{H}$ 型イオン交換法で $\mathrm{Cr}^{3+}$ として除去し, 次 いでその交換液中の $\mathrm{F}^{-}$を $\mathrm{Al}-\mathrm{Al}$ 法で光電比色法によ り測定した. この方法によって 0.2〜 $5 \mathrm{mg} / l$ の弗素を定 量することが出来, 実用的に㴖足な結果を得たので妘に 報告する.

\section{I 装是並びに試菜}

a）イオン交換筒 : 舟坂 ${ }^{3}$ ' の実験を参照し, 迅速定量 を考虑して 40〜60 mesh に砕いたダイヤイオンK（以 下 D.K. と略称す) を膨潤させて交換筒に $25 \mathrm{ml}$ を充 填し、な打. K. 層の上下端には glass wool を $2 \mathrm{~mm}$ つめた.

b) 比色装置 : F- 放び $\mathrm{Cr}^{3+}$ の定量にはセレニウム * 堺市百舌鳥東之町
光電比色装置" を使用, F- には防熱及び GI フィルタ 一を, $\mathrm{Cr}^{3+}$ には硫酸ニッケルの硫酸性溶液フィルター を夫ふ使用.

c) $\mathrm{pH}$ 測定装置 : アンチモン電極水素イオン濃度計 を使用.

d) $\mathrm{F}^{-}$を取扱うガラス器具類は緿てパラフィン引き にした.

e) $\mathrm{Cr}^{3+}$ 定量用試薬 $: \mathrm{Cr}^{3+}$ は ジフェニルカルバチッ ド法で定量した5)。

f）弗素定量用試薬 ${ }^{2}$ 及び弗素標準溶液：i） $0.1 \%$ ア ルミノン水溶液, ii) アルミニウム溶液: $\mathrm{K}_{2} \mathrm{Al}_{2}\left(\mathrm{SO}_{4}\right)_{4}$ - $24 \mathrm{H}_{2} \mathrm{O} \quad 7.300 \mathrm{~g} / 500 \mathrm{ml}$ を調製, 使用に際して 100 倍 にうすめて $0.04 \mathrm{mg} \mathrm{Al}{ }^{3+} / 5 \mathrm{ml}$ とする. iii）弗素標準 溶液 : NaF $2.2107 \mathrm{~g} / l$ を調製し 100 倍にうすめて 0.01 $\mathrm{mg} \mathrm{F}-/ \mathrm{m} l$ とする. iv) $\mathrm{HF}$ 並びに $\mathrm{NH}_{4} \mathrm{~F}$ 溶液 (電鍍 溶液添加用): HF はフェノールフタレイン (以下P. P. と略称す）で中和逆滴定法にで ${ }^{6}, \mathrm{NH}_{4} \mathrm{~F}$ は $\mathrm{CaF}_{2}$ 重量 法にて夫ふヤ使用の都度濃度を決定.

g）陽イオン交換樹脂"' ${ }^{2}$ D. K. を 40〜60 mesh に汾 砕し水籍法にて細いすのを除き重量で 10 倍量の $0.5 \mathrm{~N}$ $\mathrm{HCl}$ を加之重湯煎上で $60^{\circ} \mathrm{C}$ に 1 時間加熱し, 上層液が無 色透明になるまで繰返したものを $\mathrm{R}-\mathrm{H}$ 型とする.

h) 妨害限度検定用試薬 : i) $\mathrm{PO}_{4}{ }^{3-}$ 溶液 : $24.85 \mathrm{mg} /$ $\mathrm{m} l, \mathrm{H}_{3} \mathrm{PO}$ 、をメチールオレンジを指示薬として中和法 で標定 ii) $\mathrm{SO}_{4}{ }^{2-}$ 溶液 : $3.517 \mathrm{mg} / \mathrm{ml} \mathrm{H}_{2} \mathrm{SO}$ 。(中和法 
にて標定） iii） $\mathrm{AsO}_{4}^{3-}$ 溶液： $14.116 \mathrm{mg} / \mathrm{ml}, \quad \mathrm{As}_{2} \mathrm{O}_{3}$ $2.5130 \mathrm{~g}$ を精科し過泟の濃アルカリに溶解し $\mathrm{H}_{2} \mathrm{O}_{2}$ にて $\mathrm{Na}_{3} \mathrm{AsO}_{4}$ となし煮沸して $\mathrm{H}_{2} \mathrm{O}_{2}$ を除く iv) $\mathrm{SiO}_{3}{ }^{2-}$ 溶 液: $7.09 \mathrm{mg} / \mathrm{ml}$, 水ガラス $2.8450 \mathrm{~g} / 250 \mathrm{ml}$ を調製, この一定量を採りこれに $\mathrm{H}_{2} \mathrm{SO}_{4}$ を加えて蒸発乾涸する. これを繰り返して濾過（重量法で標定） v) $\mathrm{BO}_{3}{ }^{3-}$ 溶液: $8.108 \mathrm{mg} / \mathrm{ml}, \mathrm{H}_{3} \mathrm{BO}_{3}$ をニッケル坩城で熔融し命却後 $\mathrm{B}_{2} \mathrm{O}_{3} 1.200 \mathrm{~g} / 250 \mathrm{ml}$ を調製 vi) $\mathrm{C}_{2} \mathrm{O}_{4}^{2-}$ 溶液： 1.164 $\mathrm{mg} / \mathrm{m} i\left(\mathrm{KMnO}_{4}\right.$ にて標定） vii) $\mathrm{Cr}^{3+}$ 溶液 : $26.00 \bar{j}$ $\mathrm{mg} / \mathrm{ml}(1.5 \mathrm{~N}), \mathrm{CrCl}_{3}$ を $\mathrm{Na}_{2} \mathrm{O}_{2}$ にて酸化 (沃度法で 標定 $\left.{ }^{8}\right)$ 以上 i vii は使用の都度適当に稀瀵して用5. なお vii）液を D. K. 吸着限度検定用にも用いた。

上記試薬類は一奶分析用最純品を使用した。

\section{II 基 硕 実 臨}

\section{[A] Al-Al 法による弗震定量法の検討2”10}

F-は直接に陽イオンと呈色錯塩を作らないので, Fと錯塩を作る陽イオンに適当な発色試薬を加えて呈色化 合物を作り，ついでこの溶液に F-を加えることにより 呈色錯塩を分解する時の退色従って光学密度の減少を测 定して F- を定量している.この陽イオンとして $\mathrm{Zr}^{4+}$, $\mathrm{Th}^{4+}, \mathrm{Ti}^{4+}, \mathrm{Fe}^{3+}, \mathrm{Al}^{3+}$ 等があるが, 工業分析法とし て一般に $\mathrm{Fe}^{3+}$ 又は $\mathrm{Al}^{3+}$ を用いることが望ましいと考 えられる．定量に際して鋭敏正確を期する為には呈色錯 塩が安定（遊離昜イオンが殆んど存在しない）で，その 呈色が濃厚であり，しかも用いた陽イオンと $\mathrm{F}^{-}$の錯塩 が呈色錯塩に比して更に安定でなければならぬ. 然るに 陽イオンとの呈色錯塩及び弗化物錯塩の安定度は, その 溶液の $\mathrm{pH}$ により左右せられる.一般に $\mathrm{pH}$ が小になれ ばこれらの錯塩は不安定となり定量に対する鋭敏度は落 ちて来る. pH の大なる方が良好と思惟されるが， $\mathrm{Fe}^{3+}$ は $\mathrm{pH}$ 約 2.3 で, $\mathrm{Al}^{3+}$ は約 4.2 で沈澱し初め19'この限 度を少し越えると呈色錯塩が分解し初める. 又 $\left[\mathrm{AlF}_{m}\right]$ -(s-m) 及 $\left[\mathrm{FeF}_{m}\right]^{-(3-m)}$ の平衡恒数は $m=6$ の場合 $1.44 \times 10^{-20}$ 及約 $5 \times 10^{-16}$ で20) 呈色錯塩の安定 $\mathrm{pH}$ 限 域並びに弗化物錯塩の安定度よりいって用いる陽イオン としては $\mathrm{Fe}^{3+} よ り も ~ \mathrm{Al}^{3+}$ が良好と思われる. $\mathrm{Al}^{3+}$ との 呈色試薬としてアルミノン，エリオクロームシアニン211, ヘマトキシソン ${ }^{12}{ }^{22}$ 等があるが，他のむのに比して色調 単一であり，D.K. による $\mathrm{Cr}^{3+}$ の分離において $\mathrm{Cr}^{3+}$ が微量残存しても呈色を妨害しないので $\mathrm{Al}-\mathrm{Al}$ 法を㭘 討した。本法による F- 定量法を最初に発表したのは Osherovich $^{2)}$ であるが，その後 Feldman が追試した結 果一致しなかった ${ }^{10}$. この事に対し Osherovich は Ai$\mathrm{Al}$ 法の呈色反応が鋭敏でないと述べ，呈色操作として 発色試薬添加後一畤間放置せしめている. 著者等は以下 述べる如く種々検討を加えた結果一定条件では充分定量 可能なることを確めた。

a) 呈色伩対する検討 (i〜iv)

i) 呈色に対する温度の影響: 1) [水 $(50 \mathrm{ml})+\mathrm{NaCl}$ $(0.19 \mathrm{~g})+$ P.P. (1滴)]を $\mathrm{NaOH}$ で微赤色を呈せし め, これに Al ${ }^{3+}(5 \mathrm{ml})+N-\mathrm{HCl}\left(8 \mathrm{ml}+3 N-\mathrm{NH}_{4} \mathrm{Ac}\right.$ $(5 \mathrm{ml})+0.1 \%$ アルミン $(5 \mathrm{ml})+6 \mathrm{~N}-\left(\mathrm{NH}_{4}\right)_{2} \mathrm{CO}_{3}$ $(0.5 \mathrm{ml})+$ 水 $=100 \mathrm{ml}$, この順序に試楽を加え（以下
この操作並びに用いる試楽を Al-AIR と略称する) 水浴 中でよく振盪しながら 5 分間に夫ふの温度に.上昇せしめ て後直ちに比色する. 2)1)の比色後值ちに 5 分間に $14^{\circ} \mathrm{C}$ まで水冷して比色する. 3）1）の水 $50 \mathrm{ml}$ の代りに $\mathrm{NaF}$ $50 \mathrm{ml}\left(\mathrm{F}^{-}=500 \gamma\right)$ を用いる以外は全く同様に操作する. 4) 3) の比色後 2) と全く同様に操作する.(この時の比

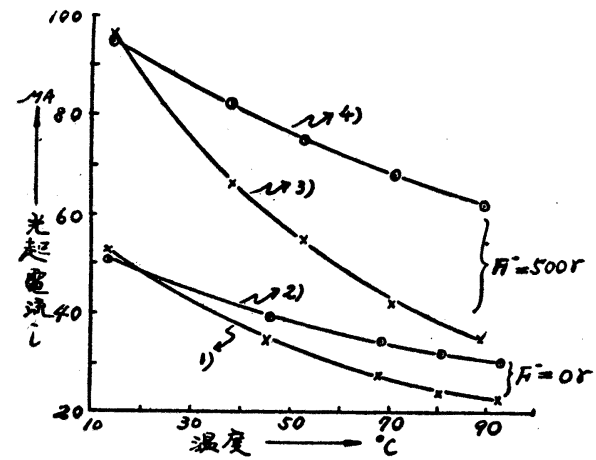

1)，3）上昇温度で直ちに比色 ( 5 分放置)

2)，4）1）及び 3) を水冾後直ちK比色(10分放置) $\mathrm{pH}=4.6$

第 1 図

色液のpH = 4.6) その結果を第 1 困に示した. 図から温度 が上昇する程呈色の増大を認めるが， $14 \sim 90^{\circ} \mathrm{C}$ 範囲で はその温度を 10 分間宛保つ場合に一定值が得られない。

ii）呈色時間率 : 反応時間の経過に伴い光起丽流の变 化が認められる. 今 F-500 $\gamma, 250 \gamma, 150 \gamma$, 及び $0 \gamma$ の $50^{\circ} \mathrm{ml}$ 溶液について夫љ i) 項と全く同様にAl-Al R を 加え $31^{\circ} \mathrm{C}$ 恒温槽中に夫љ一定時間を放置させて值ちに 比色した結果を第2図に示す.この時の比色液の $\mathrm{pH}=4.6$ 园から呈色は 45 分後に略々一定值を与えることが判る.

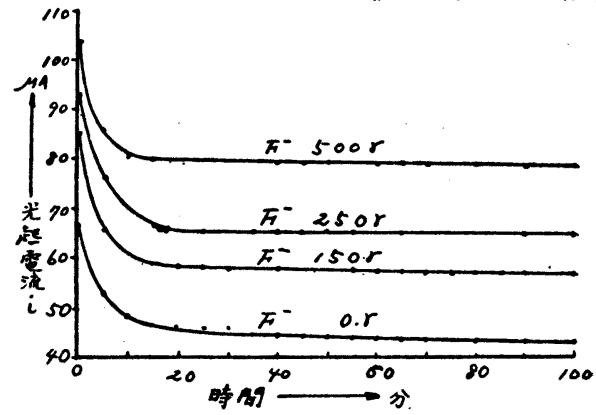

$\mathrm{pH} 4.6,31^{\circ} \mathrm{C}$ 恒温槽中下所定の時間放置後 直ちに比色

$$
\text { 第 } 2 \text { 図 }
$$

iii） $\mathrm{pH}$ と呈色の関係並びに塩類効果：本法によれ ば電鍍液中の $\mathrm{CrO}_{3}(75$ 倍に稀釈せるもの $5 \mathrm{~m}$ !) をエタ ノールと $\mathrm{HCl}$ で還元して D.K. により $\mathrm{Cr}^{3+}$ を除去 した後 P.P. と $\mathrm{NaOH}$ で微赤色迄中和する故 ( $(N / 10$ $\mathrm{NaOH} 3.25 \mathrm{~m} l$ 要した) 食塩 (約 $0.019 \mathrm{~g}$ ) か比色液中 に混在して来る. 従って標準曲線を作成するに当り食塩 による影響を検討した. 即ち $\mathrm{pH}$ と呈色の関係を求める に際して食塩の添加しないるの改び一定量 (0.19g) を 共存せしめたものについて実験を行った，F-の添加量 0 及200 r の夫ネにi）項と全く同様に Al-AlR を加え 


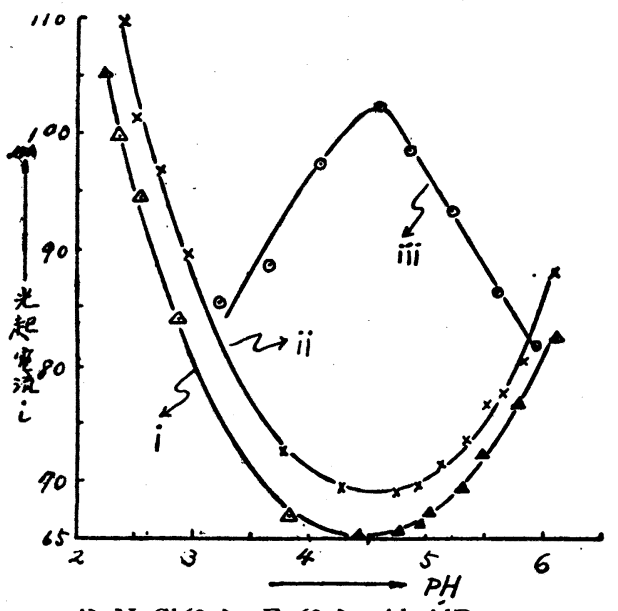

i) $\mathrm{NaCl}(0 \mathrm{~g})+\mathrm{F}^{-}(0 \gamma)+\mathrm{Al}-\mathrm{Al}^{-1 \mathrm{R}}$

ii) $\mathrm{NaCl}(0.19 \mathrm{~g})+\mathrm{F}-(0 \gamma)+\mathrm{Al}-\mathrm{AlR}$

iii) $\mathrm{NaCl}(0.19 \mathrm{~g})+\mathrm{F}-(200 \gamma)+\mathrm{Al}-\mathrm{AlR}$

第 3 図

$31^{\circ} \mathrm{C}$ 恒温槽中に 45 分間放置後比色した.なお $\mathrm{HCl}$ の 量のみを变えることにより $\mathrm{pH}$ を調節した。結果は第 3 区の如くである. 図より $\mathrm{Al}-\mathrm{Al}$ 呈色に対して明らかに塩 頝効果か現れていることが䇲われる. 又呈色の極大は $\mathrm{pH} 4.6$ であり又この $\mathrm{pH}$ が $\mathrm{AlF}_{\mathrm{B}}{ }^{3-}$ の安定から見て最 適の条件である.この事は Price ${ }^{12)}$ のアルミニウムー マトキシ ทン法による結果とよく一致し, スアルミニウ 么溶液を以て F- を電流滴定する際 $\mathrm{AlF}_{6}{ }^{3-}$ の安全存在 域が pH 4.6 であるとしている Castor ${ }^{13)}$ の結果とも一 致する.

iv）呈色に及ぼす $\mathrm{Al}^{3+}$ とアルミノン量の相対的関係: 本実験に打ける F-の測定可能量に対して必要且充分な るアルミノン量を求めんとして i) 項のアルミノン量を 变化する以外は全く同様に操作して全容 $100 \mathrm{ml}$ となし た後 $31^{\circ} \mathrm{C}$ 恒温槽中に 45 分間放置後比色した結果を第 1表に示す. 以上の結果から F- を全く添加しない場合

第 1 表 $\mathrm{Al}^{3+}(40 \gamma)$ に対するアルミノンの必要量

\begin{tabular}{lcccc}
\hline アルミノン量 $(\mathrm{ml})$ & 3 & 4 & 5 & 6 \\
電流計の振れ $(\mu \mathrm{A})$ & 62.0 & 62.5 & 60.5 & 60.5
\end{tabular}

で $5 \mathrm{ml}$ (理論值では $2.15 \mathrm{ml}$ であるが遊離の $\mathrm{Al}^{3+}$ をな くする為にもアルミノンの過剩が良い〉添加すれば充分 である。

v) 測定曲線の作製： iii) 項において $\mathrm{Al}-\mathrm{Al}$ の呈色 に塩類の影響か現れているから測定曲線作成に当っても
電鍍液中の $\mathrm{F}^{-}$の定量と条件を一致させる為に比色液に $0.019 \mathrm{~g}$ 食塩を共存せしめた. 即ち $250 \mathrm{ml} コ$ コルビ 一カーに次の操作中 $\mathrm{F}-(\mathrm{NaF})$ 量を順次量を变えてとる. $N / 10 \mathrm{NaCl}(3.25 \mathrm{ml})+\mathrm{NaF}((\mathrm{F}-$ として0〜500 y)

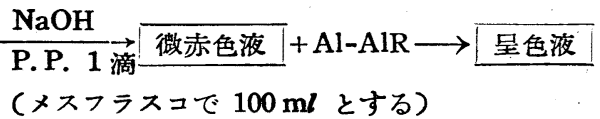

この呈色液 $100 \mathrm{~m} l$ を $100 \mathrm{~m} l$ 三角フラスコに移し， $31^{\circ} \mathrm{C}$ 恒温槽中に 45 分間放置後直ちに比色セル $(100 \mathrm{~m}$ ) に移して比色する. 比色液の $\mathrm{pH} 4.6$ 比色計は予じめ光 源に防熱用フィルター及 GI フィルターをかけ $150 \mu \mathrm{A}$ に調節して置く，この方法を 5 回繰返して第 4 図に示す 結果を得た. その繰返し精度 $\sigma 0.69 \%$ で，定量範囲は

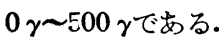

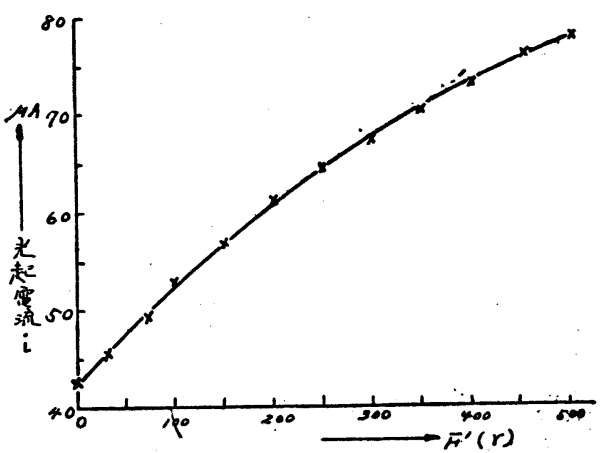

$\mathrm{pH} 4.6$ 全容 $100 \mathrm{ml} 31^{\circ} \mathrm{C}$ 恒温槽中に 45 分放置 第 4 図

b) 本呈色反応に対する妨害イオンの影響 : 本呈色 反応を妨害する共存物質としてカチオンは電鍍液中の $\mathrm{Cr}^{3+}$ を除く為に D. K. 層を通過させるから一広除き得 られるものとして残存しても微量程度である. 又これか らカチオンの $\mathrm{Be}^{++}$を除く殆んどのイオンは炭酸アンモ ンの添加によって呈色を妨害しない、11．イオン交換後通 過液中に残る $\mathrm{Cr}^{3+}(50 \gamma$, II[B]b) 項参照) 及び特に諸 種アニオンについて予じめ $\mathrm{F}^{-}$溶液中に一定量共存せし め, 発色させたる結果を第 2 表に示す. 実験条件はa)v) 項に妨害イオンを加えた以外は全く同様に行った. 以上 の結果 : $\mathrm{iO}_{3}^{--}, \mathrm{C}_{2} \mathrm{O}_{4}^{--}$は其の影響が大きい.

[B] 電鋠液中のクロム酸の分離法について

クローム鍍金液中の $\mathrm{F}^{-}$に対する $\mathrm{CrO}_{3}$ の存存比は 1: 250 前後である.故にクロームか $\mathrm{CrO}_{4}^{--}, \mathrm{Cr}_{2} \mathrm{O}_{7}^{--}$及び $\mathrm{Cr}^{3+}$ の何れの型で存在しても其の着色は強くて到底其の

第 2 表 共存イオン妨害限度 $\left(\left(\mathrm{F}^{-}\right.\right.$採取量 $\left.250 \gamma\right)$

\begin{tabular}{|c|c|c|c|c|c|c|c|c|c|c|c|c|c|}
\hline & 1 & オ & y & の & 種 & 類 & $\mathrm{SO}_{4}^{--}$ & $\mathrm{PO}_{4}^{3-}$ & $\mathrm{BO}_{3}{ }^{3-}$ & $\mathrm{SiO}_{3}^{--}$ & $\mathrm{AsO}_{4}{ }^{3-}$ & $\mathrm{C}_{2} \mathrm{O}_{4}^{--}$ & $\mathrm{Cr}^{3+}$ \\
\hline & 使 & & 用 & 物 & & 質 & $\mathrm{H}_{2} \mathrm{SO}_{4}$ & $\mathrm{H}_{3} \mathrm{PO}_{4}$ & $\mathrm{H}_{3} \mathrm{BO}_{3}$ & $\mathrm{Na}_{2} \mathrm{SiO}_{3}$ & $\mathrm{Na}_{3} \mathrm{AsO}_{4}$ & $\mathrm{H}_{2} \mathrm{C}_{2} \mathrm{O}_{4}$ & $\mathrm{CrCl}_{3}$ \\
\hline \multirow{2}{*}{\multicolumn{7}{|c|}{ I. 無妨害限度(比色時) $\mathrm{mg} / 100 \mathrm{~m} l$}} & 7.034 & 19. 88 & 4. 216 & 0.177 & 11.293 & 0.010 & 1.505 \\
\hline & & & & & & & 以 下 & 以 下 & 以 下 & 以 下 & 以 下 & 以 下 & 上 下 \\
\hline \multirow{2}{*}{ II. } & \multirow{2}{*}{\multicolumn{6}{|c|}{ 原電鍍液中の共存許容量 $\mathrm{mg} / \mathrm{m} l$}} & 105.510 & 298. 200 & 63.240 & 2.655 & 169. 395 & 0.150 & \multirow{2}{*}{-} \\
\hline & & & & & & & 以 下 & 以 下 & 以 下 & 以 下 & 以 下 & 以 下 & \\
\hline
\end{tabular}


㩇 F- を比色することは不可能である. 一方 $\mathrm{Al}-\mathrm{Al}$ 法に よって F- を比色する際の $\mathrm{Cr}^{3+}$ の最大共存許容量は Fが $250 \gamma / 100 \mathrm{ml}$ の場合で, 第 2 表より $\mathrm{Cr}^{3+} 1505 \gamma / 100 \mathrm{ml}$ であるから $\mathrm{F}^{-}: \mathrm{Cr}^{3+}=1: 6.05$ 故に何等かの方法で共 存するクローム $\left(\mathrm{CrO}_{3}\right.$ を $\mathrm{Cr}^{3+}$ に直して) を大約 $1 / 40$ 以下に分離せねばならない。このクロームの分離法とし て沈澱法 $\left(\mathrm{PbCrO}_{4}\right.$ 又は $\left.\mathrm{BaCrO}_{4}\right)$, 電解法 $\left.{ }^{14}\right)$ 及びイオ ン交換法 ${ }^{15)}$ 等が考えられるが， $\mathrm{F}^{-}$が $\mathrm{Pb}^{++}$及び $\mathrm{Ba}^{++}$ と不溶性の沈澱をつくったり，弗素が揮発性で失われ易 い点, 又工業分析法として分析操作及び時間等を考慧す ると前三者は不適当であるのでイオン交換法を採用した. 然るに原試料では弗素すクロームも共にアニオンの状態 にあるので陰イオン交換樹脂を用いる $\mathrm{F}^{-}$と $\mathrm{CrO}_{4}^{--}$の 分離法が考えられる. 井上等 ${ }^{18}$ ( は苳酸クローム踖化合物 と陰イオン交換樹脂との反応を検し，その間の置換反応 については相当複雑困難であることを指摘している. 久 Sussman 等16) の硫酸浴クローム鍍金癈液の中性溶液か ら除イオン交換樹脂 $\mathrm{R}-\mathrm{Cl}$ 型を用いて $\mathrm{CrO}_{4}$-ーを回收す る報告があるが，樹脂の酸化等の為思わしくない，一方 重クロム酸, クロム酸の還元並びに $\mathrm{Cr}^{3+}$ と $\mathrm{F}^{-}$の分離 は容易であると考えられるので $\mathrm{CrO}_{3}$ の還元並びに $\mathrm{Cr}^{3+}$ と $\mathrm{F}^{-}$の分離に関する基礎実験を行た. 第 3 表は $\mathrm{CrO}_{3}$ $0.033 \mathrm{M} / \mathrm{l}$ (原液を 75 倍に稀釈) $5 \mathrm{ml}$ を塩酸とエタ ノールでの還元を検討した結果である.この結果から最 適の条件として次の操作を規定した。

第 3 表 $\mathrm{CrO}_{3}$ を $\mathrm{Cr}^{3+}$ に還元する最谪条件の検討

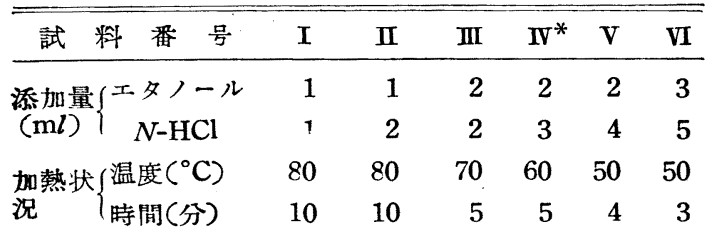

還元状況 $\mathrm{CrO}_{3} \rightarrow \mathrm{Cr}^{3+}$ 黄色 黄緑色 青色 完全 完全 完全

* IVの還元された $\mathrm{Cr}^{3+}$ 溶液のD K層通過後のpH $\fallingdotseq 2.4$

a) $\mathrm{CrO}_{3}$ の還元 : 加藤 ${ }^{17)}$ はエタノール $20 \mathrm{~m} /$ が0.1g の $\mathrm{Cr}\left(\mathrm{CrO}_{3}\right.$ として約 $\left.0.2 \mathrm{~g}\right)$ を還元すると報告された か， $\mathrm{F}^{-}$を逃さぬ為成可く低温 $\left(60^{\circ} \mathrm{C}\right)$ 且短時間 ( 5 分 間)で還元を行 5ための条件は第 3 表より $1 N-\mathrm{HCl} 2.5$ $3 \mathrm{ml}$, エタノール $2 \mathrm{ml}$ である.なおこの還元された $\mathrm{Cr}^{3+}$ 溶液の交換筒通過後の $\mathrm{pH}$ は 2.4 であった.

b) D.K. による $\mathrm{Cr}^{3+}$ の除去：一般に $\mathrm{Fe}^{3+}, \mathrm{Al}^{3+}$, $\mathrm{Cr}^{3+}$ 等の如き加水分解を起し易いイオンの交換は難しく， かかるものの交換は $\mathrm{R}-\mathrm{Na}$ 型より $\mathrm{R}-\mathrm{H}$ 級が良いとされ ている ${ }^{15)}$. 著者等の追試結果む $\mathrm{R}-\mathrm{H}$ 型が良かったので・ これに従った。（実験結果省略）

霓鍍液中の $\mathrm{Cr}^{3+}$ を $\mathrm{F}-$ 及び $\mathrm{SO}^{-2}$ より分離するに 当っての濃度及び其の量は樹脂の交換平衡から $0.1 \mathrm{~N}$ $\mathrm{Cr}^{3+}{ }^{3)} 5 \mathrm{ml}\left(\mathrm{Cr}^{3+} 0.1 \mathrm{~g}\right.$ 以下)程度を交換筒通過後の $\mathrm{pH}$ 1.5 以上で操作すれば $\mathrm{Cr}^{3+}$ は除去出来ると考えられる. 先ず電鍍液を 75 倍にうすめ，この $5 \mathrm{ml}$ を $1 \mathrm{~N}-\mathrm{HCl} 2.5$ $\sim 3 \mathrm{ml}$ 及びェタノール $2 \mathrm{ml}$ を加えて重偒朔上で 5 分間 $60^{\circ} \mathrm{C}$ に温めて $\mathrm{Cr}^{3+}$ に還元する. この溶液を $3 \mathrm{ml} / \mathrm{min}$.
の流速て交換筒を通過せしめ $60 \mathrm{ml}$ (3 回にわけて) の 水で洗浲し，通過液と洗液を合せたものについてジフェ ニールカルバチッドによる比色定量を行った結果吸着さ れずに漏出した $\mathrm{Cr}^{3+}$ 量は $50 \gamma$ 程度であった. (実験結果 省略なお D. K. の再生活性化は $1 N-\mathrm{HCl}$ で行った.)

c) D.K. による F- の交換損失： NaF を添加する 代りに $\mathrm{HF}$ 又は $\mathrm{NH}_{4} \mathrm{~F}$ 溶液の既知量をその儘直ちに加 えるか又はD.K. を通過させて後加える（洗液共に）以 外は全く[A] a）v）同様に操作し第 4 表を得た.

第 4 表 D.K. による F- の交換損失

\begin{tabular}{|c|c|c|c|c|c|}
\hline \multirow{2}{*}{$\begin{array}{l}\text { 試料 } \\
\text { 番号 }\end{array}$} & \multicolumn{2}{|c|}{$\mathrm{F}^{-}$の採取量 $(\gamma)$} & \multicolumn{2}{|c|}{$\begin{array}{l}\text { 測定曲線より求め } \\
\kappa \mathrm{F}^{-} \text {量 }\end{array}$} & \multirow{2}{*}{$\begin{array}{l}\text { 誤 } \\
\text { 百分率 } \\
\end{array}$} \\
\hline & HF & $\mathrm{NH}_{4} \mathrm{~F}$ & $\begin{array}{l}\text { 電流計の } \\
\text { 振れ }(\mu \mathrm{A})\end{array}$ & $\mathrm{F}^{-}$量 $(\gamma)$ & \\
\hline 1 & 17 & & 58.8 & & +1.11 \\
\hline 2 & 450.2 & & & & +0.84 \\
\hline 3 & & & 64.5 & & -0.91 \\
\hline 4 & & 134.5 & 55.5 & 134.0 & -0.37 \\
\hline
\end{tabular}

備考 1 及び 3 は採取試料を D.K. 層を通過させて 後测定せるもの.

2 及び 4 は試料採取後直接測定せるるの.

以上の結果から D. K. による F- の交換損失むなく 分分析誤差約 $1 \%$ で Al-Al 法による F- 定量が可能で ある.

d）電解法による $\mathrm{Cr}^{3+}$ の除去 : $\mathrm{Cr}^{3+}$ の電解還元は 相当困難とされているが著者等は Melaven ${ }^{14)}$ の晲解槽 を用いて陰極水銀及電解液を絶えず䚓汼し，页電解槽の 外部を水冷しながら次の条件で電解を行った．電解条件 陰極水銀面積約 $20 \mathrm{~cm}^{2}$, 陽極白金板面積 $1 \mathrm{~cm}^{2}$, 両極間 の間隔 $1 \mathrm{~cm}$ 電解留源電圧 $12 \mathrm{~V}$, 電解電流 $0.82 \sim 0.85$ $\mathrm{A}$, 電解液は電鍍液 75 倍に稀瀵せるもの $5 \mathrm{ml}$ を $\mathrm{HCl} 3$ $\mathrm{m} l$ とエタノール $2 \mathrm{~m} l$ で還元し水で $35 \mathrm{~m} l$ に稀鄱せる

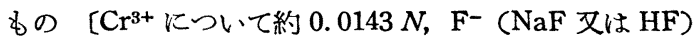
$250 \gamma \sim 360 \gamma / 35 \mathrm{ml}$ ] は約 50 分で $\mathrm{Cr}^{3+}$ が還元除去され た. 還元後靦䢁を止め電流を通じながら水銀を除いてか ら電流をたち、コックを切替えて流出する液を東洋滤紙 No. $5 \mathrm{C}$ で濾過する. クロームは Amalgam を作り難 いので電解液が摜找とか電解条件で稍々濁ることがある. 留解時間を速める為に陽極面積を大にし鼠流を $2.5 \mathrm{~A}$ 位 にすると約 25 分位で除去出来るが，電解液が濁り滤過 してもなお液が灰色がかっている. 電流は1. 5 A迄で40 分位が良い，可論電解液の $\mathrm{Cr}^{3+}$ についての濃度が大な る場合は電流を小さくすれば夜は濁らぬ.なお䚌找は余 り激しいと電解液中に金属クロームが拡散するものた如 く，摫䢁器の羽根が水銀面をなでるように摫抖すること か最も良かった. 以上の最適条件で $\mathrm{Cr}^{3+}$ を除去せる雷 解液を P. P., $\mathrm{NaOH}$ で微赤色を呈せしめ以下II, [B] c) 項通り操作し F- の定量した結果第 5 表に示す如く 常に一定值は得られず，添加 $\mathrm{F}^{-}$量の約 70〜90\% 㷙後 の測定值を得るにすきぬ. 以上の結果から還流冷却器を 附せずに行5 Melaven 法による $\mathrm{Cr}^{3+}$ 除去操作は本 F定量法に適しないと思惟される.

III 分 析 指 針

Al-At 法による $\mathrm{Cr}$ 鍍金液中の $\mathrm{F}-$ 定量指針：以上 
第 5 表 電解還元による $\mathrm{Cr}^{3+}$ 除去後の $\mathrm{F}^{-}$測定結果

\begin{tabular}{|c|c|c|c|c|c|c|c|}
\hline \multirow{2}{*}{$\begin{array}{l}\text { 試料 } \\
\text { 番号 }\end{array}$} & \multirow{2}{*}{\multicolumn{2}{|c|}{$\begin{array}{lc}\mathrm{F}^{-} \text {添 } & \text { 加 } \\
\mathrm{NaF} & \text { 量 }(\gamma) \\
\end{array}$}} & \multicolumn{2}{|c|}{ 測 定 結 果 } & \multirow{2}{*}{$\begin{array}{c}\text { 愦 } \\
\text { 差 }(\gamma)\end{array}$} & 差 & \multirow{2}{*}{$\begin{array}{l}\text { 測定傎の添加量 } \\
\text { К対する百分率 }\end{array}$} \\
\hline & & & $\mu \mathrm{A}$ & $\mathrm{F}^{-}(\gamma)$ & & 百 分 率 & \\
\hline $\begin{array}{l}1 \\
2 \\
3\end{array}$ & $\begin{array}{l}250 \\
250\end{array}$ & 360 & $\begin{array}{l}61.5 \\
63.5 \\
64.8\end{array}$ & $\begin{array}{l}210 \\
235 \\
245\end{array}$ & $\begin{array}{l}-\quad 40 \\
-\quad 15 \\
-115\end{array}$ & $\begin{array}{l}-16.00 \\
=\quad 6.00 \\
-\quad 31.94\end{array}$ & $\begin{array}{l}84.00 \\
94.00 \\
68.06\end{array}$ \\
\hline 4 & & 360 & 69.5 & 320 & -40 & -11.11 & 88.89 \\
\hline
\end{tabular}

第 6 表 電鍍液中の $\mathrm{F}^{-}$測定結果

電鍍液組成 $\mathrm{HF}(x \cdot g): \mathrm{CrO}_{3}(\mathrm{~g}) / l$ の場合

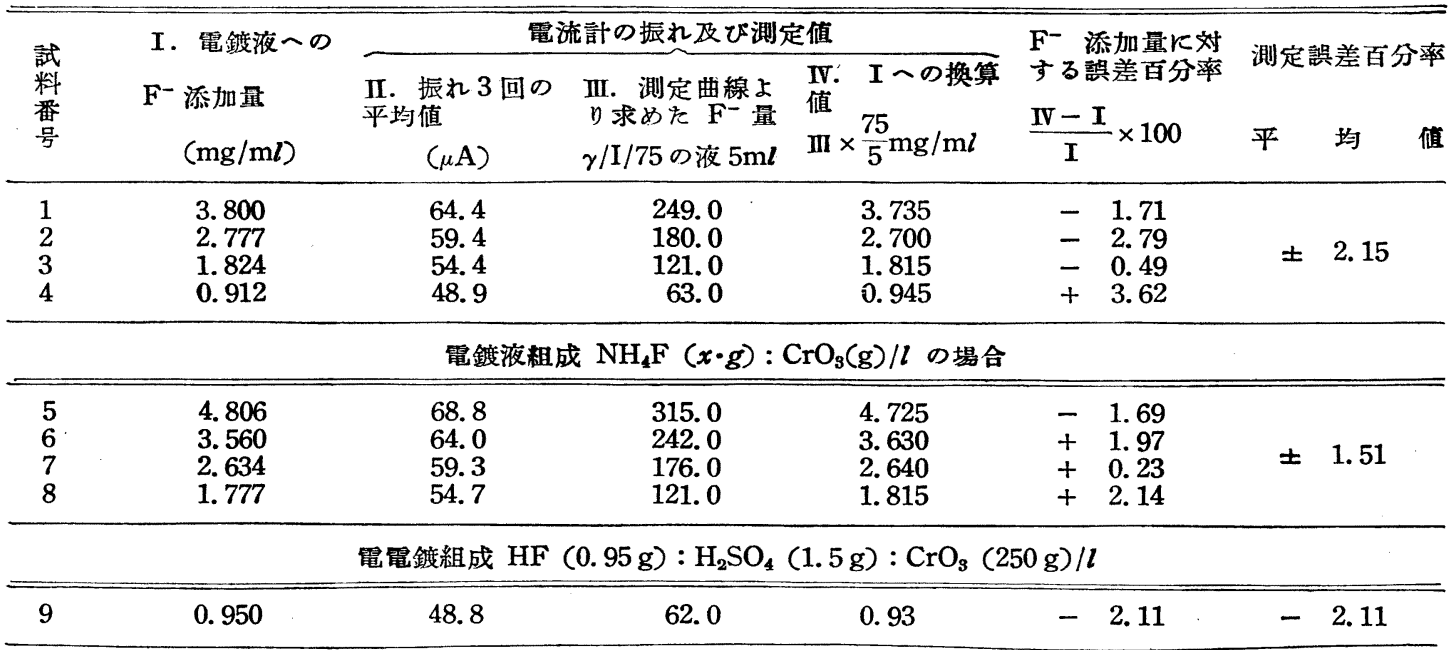

大阪市内荣会社の笔鍍液試料 (組成 $\mathrm{NH}_{4} \mathrm{~F}: \mathrm{H}_{2} \mathrm{SO}_{4}:: \mathrm{CrO}_{3} 250 \mathrm{~g} / l$ )

\begin{tabular}{|c|c|c|c|c|}
\hline \multicolumn{3}{|c|}{$\begin{array}{l}\text { 電鍍液 } 75 \text { 倍飞 } \\
\text { 中のすめ } \mathrm{F}^{-} \text {測定值 }\end{array}$} & \multirow{2}{*}{$\begin{array}{c}\text { III'. 原液 } 1 \text { l のの } \mathrm{F}^{-} \text {換算值 }(\mathrm{g} / \mathrm{l}) \\
\mathrm{II}^{\prime} \times \frac{75}{5} \times 1000\end{array}$} & \multirow{2}{*}{$\begin{array}{c}\mathrm{IV}^{\prime} \mathrm{F}^{-} \text {と当量の } \mathrm{NH}_{4} \mathrm{~F} \text { 換算値 } \\
(\mathrm{g} / l)\end{array}$} \\
\hline $\mathbf{I}^{\prime}$ & 振れ $(\mu \mathrm{A})$ & $\begin{array}{l}\text { II }^{\prime} \text { 測定曲線上 } \\
\text { y求めた F } \text { F }^{-} \text {量 }\end{array}$ & & \\
\hline & 46.2 & 36.0 & 0.540 & 1. 051 \\
\hline
\end{tabular}

の実験結果を綜合して次の実験指針を樹てた. 試料 10 $\mathrm{m} l$ (濁っている時は滤過水洗洗液共) 加えて 75 倍にうすめ,・その $5 \mathrm{ml}$ を $250 \mathrm{ml}$ のコニカ ルビーカーに採りエタノール $2 \mathrm{~m} l$ 及び $N-\mathrm{HCl} 3 \mathrm{ml}$ と 共に重湯煎上で約 5 分間 $60^{\circ} \mathrm{C}$ に片熱還元後 D.K. の 交換層を $3 \mathrm{~m} l / \mathrm{min}$. の流速で通過させ $60 \mathrm{~m} l$ の蒸溜水 を 3 回に分けて洗滌し濾液に洗液を合しこれをP.P. 微 赤色迄 $\mathrm{NaOH}$ を添加する 次に明攀液 $5 \mathrm{ml}\left(\mathrm{Al}^{3+}\right.$ と 乙て $40 \gamma$ ), $N$ - $\mathrm{HCl} 8 \mathrm{~m} l, 3 N-\mathrm{NH}_{4} \mathrm{Ac} 5 \mathrm{~m} l, 0.1 \%$ アルミノン $5 \mathrm{ml}$, 及び $6 \mathrm{~N}-\left(\mathrm{NH}_{4}\right)_{2} \mathrm{CO}_{3} 0.5 \mathrm{~m} l$ を順序 飞加兄水にて全容を $100 \mathrm{ml}$ となし $(\mathrm{pH} \mathrm{4.6)} \mathrm{これを}$ $100 \mathrm{~m} l$ 三角フラスコに入れ $31^{\circ} \mathrm{C}$ 恒温槽中で 45 分間放 置呈色後比色する. 光雷此色計を用いて子じめ求めてあ る測定曲線より $\mathrm{F}^{-}$量を求めた.

\section{IV 分析結果並びに考案}

本法によって分析した結果を第 6 表に示す. 以上の結 果から分析誤差約 $2 \%$, 所要時間 75 分であって標題鍍 金液中の弗素の制御分析に打ける従来の誤差 $5 \%$ に比し 充分な精度がある. 更に従来法より著しく分析所要時間 を短縮し得たので F- の制御用分析法として充分なるむ のと考光る.な拈 $\mathrm{H}_{2} \mathrm{SiF}_{6}$ 及び $\mathrm{HBF}_{4}$ の添加物弗素定量
については目下研究中である.

終りに臨み本研究を遂行するに当り本学石田教授より 御茬切なる御指導を賜り且つ実際の工場試料を多数提供 下されたことに対し深謝する.

(昭和 28 年 4 月 2 日・日本化学会第 6 年会にて講演発表)

$$
\text { 女献 }
$$

1) T. A. Hood : Metal Finishing, 50, 103 (1952).

2) R. E. Osherovich : Zavodskaya Lab., 7, 934(1938); C. A., 33, 8140 (1939).

3) 舟坂渡, 河根誠, 端野朝康 : 工化., 54, 355 (1951).

4) 武者：日化., 71, 538, (1950).

5) Frank J. Welcher : Org. Anal. Reagents, II, 434 (1949).

6) Treadwell Hall : Anal. Chem., 2, 523 (1953).

7) Wilfred W. Scott : Standard Methods of Chem. Anal., I, 404 (1939).

8) ibid., I, 288 (1939).

9) 武藤覚, 日化., 72, 976 (1951).

10) M. M. Feldman, R.E. Osherovich : Zavodskaya Lab., 9, 127 (1940) ; C. A., 37, 6587 (1943).

11) Frank J. Welcher : Org. Anal. Reagents, II, 100 (1948).

12) Margaret J. Price, Osman J. Walker : Anal. 
Chem., 24, 1593 (1952).

13) C. R. Castor, J. H. Saylor : Anal. Chem., 24, 1369 (1952).

14) A. S. Melaven : Ind. Eng. Chem. Anal. Ed., 2, 180 (1930).

15) 本田雅健 : 分化., 2, 155 (1953).

16) Sidney Sussman, Frederich C. Nachod, William Wood : Ind. Eng. Chem., 37, 618 (1945).
17) 加藤虎郎：標準定量分析法, 162 (1939).

18）井上吉之, 川村亮, 和田敬三, 岡村浩 : 分化., 2, 21 (1953).

19) Hillebrand, Lundell : App. Inorg. Anal., II Ed., 76 (1953).

20) Latimer: Oxy. Pot., 281 \& 226 (1952).

21) W. E. Thrun : Anal. Chem., 22, 918 (1950).

22）奥野久輝：日化., 63，23 (1942).

\title{
(京都大学化学研究所 ${ }^{*}$ ) (昭和 29 年 3 月 31 日受理)
}

\section{陰イオン交換樹脂による定性分析}

\author{
滝 山一善・水 渡 英 二
}

\section{Qualitative Analysis by means of Anion Exchange Resin}

\author{
Kazuyoshi TakiYama and Eiji Surto \\ (Institute for Chemical Research, Kyoto University)
}

Anion exchange resin (Amberlite IRA-410) was used as $\mathrm{RCl}, \mathrm{RS}, \mathrm{ROH}$ and $\mathrm{RCO}_{3}$ forms. At first the sample solution was passed through the column of $\mathrm{RCl}$ form exchanger. The first group metals precipitated as chloride. The precipitates were filtered and the filtrate was passed through the column of $\mathrm{RS}$ form exchanger. The second and the third group metals except $\mathrm{Al}$ and $\mathrm{Cr}$ precipitated as sulfide. The solution containing these precipitates was acidified by $\mathrm{HCl}(0.3 N)$. The precipitates of the third group metals were dissolved, while those of the second group metals do not. The latter were filtered and the filtrate was passed through the column of ROH form exchanger. The third group metals and $\mathrm{Mg}$ precipitated as hydroxide. By the addition of $\mathrm{NH}_{4} \mathrm{Cl}$ to the suspension, $\mathrm{Mg}(\mathrm{OH})_{2}$ alone was dissolved. The precipitates of the third group metals were filtered and the filtrate was passed through the column of $\mathrm{RCO}_{3}$ form exchanger. The fourth group metals precipitated. The precipitates were filtered and the filtrate containing the fifth group metals was treated by RH form cation exchanger. The precipitates of each group metals were determined by usual method of qualitative analysis. The $\mathrm{RCl}, \mathrm{RS}, \mathrm{ROH}$ and $\mathrm{RCO}_{3}$ form anion exchange resins were regenerated by $\mathrm{HCl}$, yellow ammonium sulfide, $\mathrm{NaOH}$ and $\left(\mathrm{NH}_{4}\right)_{2} \mathrm{CO}_{3}$ respectively.

(Rंeceived March 31, 1954)

\section{I 緒 带}

陽イオン交換樹脂または陰イオン交換樹脂に，種及の 陽イオンまたは陰イオンをあらかじめ交換吸着により飽 和せしめておきこれらの陽イオン又は陰イオンと沈澱 を生ずるが如き院イオンまたは陽イオンを有する塩類溶 液を作用せしめると，それぞれ相当した沈澱またはコ口 イドを生成すべきである，しかも最良の条件では反応イ オンに過不足なく当量のイオンが交換し, 単独塩溶液か ら純粋な沈澱或はコロイドを生成する．著者等はかくの 如き方法による沈澱生成に関して研究しているか，本報 告においてはかかる現象を定性分析に打ける陽イオンの 各族の沈澱生成に利用した実験について述べる.

S. Gaddis ${ }^{1)}$ は Amberlite IR-4 に $\mathrm{H}_{2} \mathrm{~S}$ を飽和せし めてビーカー中で第 2 族の硫化物沈澱の生成に利用した. 著者等は $\mathrm{RCl}$ 形, $\mathrm{RS}$ 形, $\mathrm{ROH}$ 形及び $\mathrm{RCO}_{3}$ 形等の 陰イオン交換樹脂を使用して, カラム法によって第 1 そ 至第 4 族の各沈澱を順次別々に生成せしぬた。

\section{II イオン交換㯕脂及び装置}

陰イオン交換樹脂としては平均 30 メッシュの球形の 强塩基性樹脂 Amberlite IRA-410 を塩素形 ( $\mathrm{RCl}$ 形), 硫黄形 ( $\mathrm{RS}$ 形), 水酸化物形 ( $\mathrm{ROH}$ 形) 及び炭酸塩形

* 大阪府高柣市古筸部
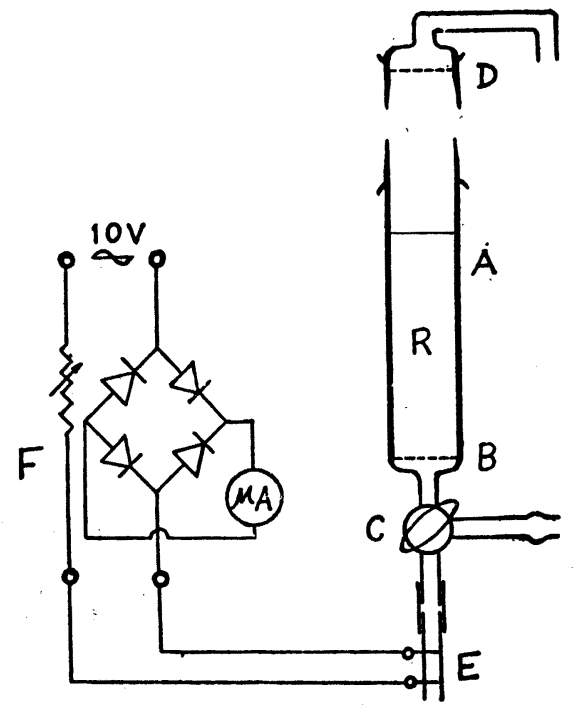

第 1 圀 院イオン交換樹脂による沈澱生成装置 $\left(\mathrm{RCO}_{3}\right.$ 形) として夫々約 $10 \mathrm{cc}$ (水中における体積) を 使用した. 樹脂を各イオン形とするには後述の樹脂の再 生の項に述べる方法による. 